\title{
OBITUARIES
}

\section{Sir William Mitchell, K.C.M.G.}

Sir William Mitchell, emeritus professor of philosophy, former vice-chancellor and chancollor of the University of Adelaide, died in Adelaide on June 24 at the age of 101 .

Sir William was born at Inveravon, Banffshire, Scotland, in March 1861. He received his early education at Elgin and later entered the University of Edinburgh, where he graduated M.A. and D.Sc. in philosophy.

His first appointment was as lecturer in ethics in the University of Edinburgh, and from there ho went to University College, London, as lecturer in education. Later, he was appointed examiner in philosophy at Edinburgh and in the theory of education at the University of Cambridge.

In 1894 he joined the University of Adelaide as Hughes professor of English language and literature and mental and moral philosophy. From the beginning of his professorship, he took an active part in the government of the University, and in 1896 was elected to its Council. Sir William became vicechancellor in 1916 and held this office continuously until 1942. In 1927, he was created a Knight Com. mander of the Order of St. Michael and St. George. On the death of Sir George Murray in 1942, he was elected chancellor of the University. He relinquished that office on January $31,1948$.

Sir William was counted among the distinguished philosophers of his day. In 1924, he was invited to deliver the Gifford Lectures in the University of Aberdeen, and in 1934 he delivered the philosophical address of the year to the British Academy. But perhaps his greatest contribution to scholarship was his work as a teacher. He had a singular and powerful gift for enabling those whom he taught to discover where their deepest interests lay and to develop themselves with confidence and vigour.

$\mathrm{He}$ was also remarkable for the natural and most acceptable leadership which he exercised throughout his long service as a member of the governing body and as vice-chancellor of the University of Adelaide. $\mathrm{He}$ bore his years lightly, and his spare, vigorous figure was often to be seen in the University after he had passed his eightieth birthday. Indeed, he enjoyed remarkable health and mental vigour until a serious illness beset him in 1958. From this he recovered, but was thereafter much restricted in his activities. He kept until the end of his long life a graciousness and serenity which made and preserved for him many friends.

He is survived by a daughter, Mrs. J. R. Thomson, and a son, Sir Mark Mitchell, professor of biochemistry and general physiology and deputy vice-chancellor of the University of Adelaide.

H. B. BASTEN

\section{Prof. Granville Poole}

Prof. Granville Poole, emeritus professor of mining engineering in King's College, Newcastle upon Tyne (University of Durham), died on May 26, aged seventy-six.
Prof. Poole was a man of outstanding character who commanded respect not only by his ability as a mining engineer of wide experience, but also by his sincerity and deep interest in all matters relating to safety in mines. He was a tall, straight, distinguished man, identified by his wing collar and bow tie, and as we know him, with a gentle manner and a commanding personality.

His students at Armstrong College (later King's College), Newcastle upon Tyne, where he held the Milburn chair of mining engineering from 1923 until 1951, will always remember his custom of sitting with them in the front row of the lecture theatre and illustrating his lectures by recalling incidents in his earlier career in the Inspectorate and at the Ministry of Mines.

His experience was unique in the coal-mining industry in that he was associated, as private secretary to H.M. Chief Inspector of Mines during 1911-13, with the passing of the 1911 Coal Mines Act and again in 1954 as an adviser to the National Union of Mineworkers Parliamentary Committee when the 1954 Coal Mines Act was being formulated.

His career belies present-day beliefs, in that as a young graduate from the University of Birmingham he was given responsibility at the early age of twentyfour as one of H.M. Inspectors of Mines in 1909. He gained promotion in the Inspectorate to senior rank in 1917. His appointment to the chair of mining at the University of Leeds in 1919 when only thirtythree must also make him one of the youngest mining engineers of his era ever to hold a chair. He moved to Newcastle upon Tyne and the Milburn chair of mining at Armstrong College in 1923, following the retirement of Prof. Henry Louis.

It was at Armstrong College, which became King's College in 1929, that Prof. Poole was responsible for securing the funds for building the present Department of Mining Engineering. He was a justifiably proud and happy man in 1929 when the Prince of Wales formally opened the new building. This Mining Engineering Department was unique and well equipped and established a permanent building in a College which had taught mining engineering subjects as long ago as 1865 .

Prof. Poole was an active member of the Institution of Mining Engineers from 1908, first as a member of the South Staffordshire Institute and later of the North of England Institute of Mining and Mechanical Engineers. He was a member of Council from 1935, a vice-president from 1945 and president of the North of England Institute during 1950-52. It was particularly appropriate and was a great personal honour and pleasure that he was the president during the Centenary Celebrations of this Institute in 1952 .

$\mathrm{He}$ was widely consulted in mining matters and retained his links with the Staffordshire Coalfield as a consultant to the Shelton Iron and Steel Co.

Prof. Poole will, however, always be remembered by his students as a man who set the highest example in integrity and loyalty and for his continual encouragement to those who passed from the University into the industry. $\quad$ E. L. J. Pоттs 